Bangladesh J. Bot. 47(4): 893-901, 2018 (December)

\title{
CONSTITUENTS OF ESSENTIAL OILS FROM LEAVES AND SEEDS OF LAURUS NOBILIS L.: A CHEMOTAXONOMIC APPROACH
}

\author{
OMEr ElKiran*, Emel AKBaba $^{1}$ and EyUP BAgCi ${ }^{1}$ \\ *Department of Bioengineering, Faculty of Engineering \& Architecture, \\ Sinop University, Sinop-Turkey
}

Keywords: Laurus nobilis, Essential oil, Eucalyptol, $\alpha$-terpinyl acetate

\begin{abstract}
In the present study, chemical compositions of essential oils from seeds and leaves of laurel (Laurus nobilis L.) were evaluated using GC-GC/MS system. Sixty nine different compounds were identified constituting $86.7 \%$ of the total oil from the seed, while 76 compounds were determined, constituting $95.8 \%$ of the total oil extracted from the leaves. The major compounds of essential oil from laurel seeds included eucalyptol (17.2\%), $\alpha$-terpinyl acetate $(9.0 \%)$, caryophyllene oxide $(6.1 \%)$, spathulenol $(5.0 \%)$ and methyl eugenol (4.2\%), constituting $41.5 \%$ of the total oil. However, eucalyptol $(18.0 \%), \alpha$-terpinyl acetate $(13.1 \%)$, sabinene (7.8\%), $\alpha$-pinene (4.5\%), 2 (4-methoxyphenyl)-N,N,2-trimethyl-1-pyrroline (4.4\%) were identified as the major compounds in the oil from laurel leaves, constituting $47.8 \%$ of the total oil. Eucalyptol and $\alpha-$ terpinyl acetate, belonging to monoterpenoids, were determined in the highest concentrations within both oils. However, the other principle compounds differ between the two volatile oils.
\end{abstract}

\section{Introduction}

Laurus nobilis L. is the member of the family Lauraceae which comprises 32 genera and about 2,000 - 2,500 species (Chahal et al. 2017, Garg et al. 1992). The leaves of L. nobilis are short, thick and its fresh leaves are in red tinged yellow color which turns into light green with light green veins. They also have little aromatic odor. The fresh shoots are green, while the following is red, black and hairless. Their maximum length is known as $2 \mathrm{~cm}$ (Y1lmaz and Deniz 2017, Yazıc1 2002). L. nobilis, commonly known as bay, sweet bay and laurel, is an evergreen tree native to the south part of Europe and the Mediterranean region specially in Turkey, Greece, Spain, Italy and France. Turkey is one of the main producers and suppliers of bay leaves (Demir et al. 2004).

The essential oil (EO) and extracts from medicinal and aromatics plans may contain a wide variety of free radical scavenging molecules, such as phenolic compounds, nitrogen compounds, vitamins, terpenoids, and some other endogenous metabolites, which are rich in antioxidant activity (Pirbalouti et al. 2013).

L. nobilis is a plant of industrial importance and used in foods, drugs, and cosmetics. The dried leaves and essential oils are used extensively in the food industry for seasoning of meat products, soups and fishes. Its antimicrobial and insecticidal activities are among the factors for which bay is used in the food industry as a food preservative. The fruits contain both fixed and volatile oils, which are mainly used in soap making (Bozan and Karakaplan 2007). Traditionally it is used against rheumatism and dermatitis (Kilic et al. 2004), gastrointestinal problems, such as epigastric bloating, impaired digestion, eructation, and flatulence. The aqueous extract is used in Turkish folk medicine as an anti-hemorrhoidal, anti-rheumatic and diuretic, as an antidote in snake bites and for the treatment of stomachche (Gulcin 2006, Baytop 1984, Aqili 1992). Recently it is used in treating diabetes and preventing migraine (Duke 1997, Patrakar et al. 2012). In addition, recent studies of laurel seeds and leaves extracts have been carried out for antioxidant, antiepileptic

*Author for correspondence: <omer_elkiran@hotmail.com>. ${ }^{1}$ Department of Biology, Faculty of Science, Firat University, Elazig-Turkey. 
(Simic et al. 2003), gastro protective (Afifi et al.1997), antibacterial, antifungal (Erturk 2006), analgesic and anti-inflammatory activities (Sayyah et al. 2003, Isbilir et al. 2008). Since Turkey is one of the main producers and suppliers of the plant, it is important to provide the good quality of laurel products, in which essential oils constitute a big portion. Thus the aim of the present study was to carry out the chemical composition of essential oils from leaves and seeds of Laurus nobilis.

\section{Materials and Methods}

Laurus nobilis specimens were collected from natural habitats in Black Sea region, Sinop, Turkey. The leaves and seeds were dried in the shade at room temperature. The specimens were studied at Sinop University, Scientific and Technological Research Application and Research Center, Sinop and Firat University, Plant Products and Biotechnology Research Laboratory (BUBAL), Elazig, Turkey.

Air-dried aerial parts of the plant materials $(100 \mathrm{~g})$ were subjected to hydro distillation using a Clevenger-type apparatus for $3 \mathrm{hrs}$ to extract the essential oil.

The essential oil was analyzed using HP 6890 GC equipped with a FID detector and an HP-5 MS column $(30 \mathrm{~m} \times 0.25 \mathrm{~mm}$ i.d., film thickness $0.25 \mu \mathrm{m})$ and the capillary column were used. The column and analysis conditions were the same as in GC-MS. The percentage composition of the essential oils was computed from GC-FID peak areas without correction factors.

The oil samples were analyzed by GC-MS, using a Hewlett Packard system. HP-Agilent 5973N GC-MS system with 6890 GC is in Plant Products and Biotechnology Res. Lab. (BUBAL) at Firat University. HP-5 MS column $(30 \mathrm{~m} \times 0.25 \mathrm{mmi}$. d., film thickness $0.25 \mu \mathrm{m})$ was used with helium as the carrier gas. Injector temperature was $250^{\circ} \mathrm{C}$, split flow was $1 \mathrm{ml} / \mathrm{min}$. The GC oven temperature was kept at $70^{\circ} \mathrm{C}$ for $2 \mathrm{~min}$ and programmed to $150^{\circ} \mathrm{C}$ at a rate of $10^{\circ} \mathrm{C} / \mathrm{min}$ and then kept constant at $150^{\circ} \mathrm{C}$ for $15 \mathrm{~min}$ to $240^{\circ} \mathrm{C}$ at a rate of $5^{\circ} \mathrm{C} / \mathrm{min}$. Alkanes were used as reference points in the calculation of relative retention indices (RRI). MS were taken at $70 \mathrm{EV}$ and at a mass range of $35-425$. Component identification was carried out using spectrometries electronic libraries (WILEY, NIST). The identified constituents of the essential oils are listed in Table 1. The chromatograms were obtained and are shown in Figs 1 and 2.

\section{Results and Discussion}

For the purpose of studying the chemical composition of the essential oils (EOs) of different parts of Laurus nobilis were collected from Sinop, Turkey. EOs of dried leaves and seeds of $L$. nobilis were analyzed by GC and GC-MS in terms of their chemical composition. The results of the analysis of EOs of L. nobilis leaves are presented in Table 1 and in Fig. 1. A total of 107 compounds were identified, in which 38 of them were in common. In the essential oil of laurel leaves, 76 compounds were identified, representing $95.8 \%$ of the total oil (Fig. 1). While eucalyptol $(1,8$-cineole) was at the highest percentage (18.0), $\alpha$-terpinyl acetate $(13.1 \%)$, sabinene (7.8\%), $\alpha$-pinene (4.5\%), 2 (4-methoxyphenyl)-N, N, 2-trimethyl-1-pyrroline (4.4\%) were also detected as the major compounds in the oil profile (Table 1). In the case of L. nobilis EO from the seeds, 69 compounds were identified, representing $86.7 \%$ of the total oil (Fig. 2). Eucalyptol was detected to be present at the highest percentage (17.2) in the laurel seed EO. The presence of $\alpha$ terpinyl acetate $(9.0 \%)$, caryophyllene oxide $(6.1 \%)$, spathulenol $(5.0 \%)$ and methyl eugenol (4.2\%) was also important for the oil profile (Table 1).

While the main components of EO of the leaves of laurel consist of monoterpenes, the main components of the seed EO are mono-(1,8-cineole, $\alpha$-terpinyl acetate) and sesquiterpenes (sabinene, $\alpha$-pinene). 2-(4-methoxyphenyl) -N, N, 2-trimethyl-1-pyrroline was the major 
compound in the $\mathrm{EO}$ of leaves, but it was not detected in the $\mathrm{EO}$ of the seeds. Comparison of the compositions between two oils showed that the amounts of sabinene, linalool and eugenol were higher in the EO of leaves than those of the seeds. In addition, the seed oil contained caryophyllene oxide and spathulenol with higher concentration than oils of leaves.

There are a many studies on chemical compositions of the EO obtained from the leaves of L. nobilis from different locations of the world, but studies on seed EOs are scarce (Bouzouita et al. 2001, Verdian-rizi 2009, Yalçın et al. 2007, Conforti et al. 2006, Kovacevic et al. 2007, Ramosa et al. 2012, Sellami et al. 2011, Caputo et al. 2017, Pinheiro et al. 2017, Y1lmaz and Deniz 2017, Peixoto et al. 2017). The present results are more or less similar to the results previously reported.

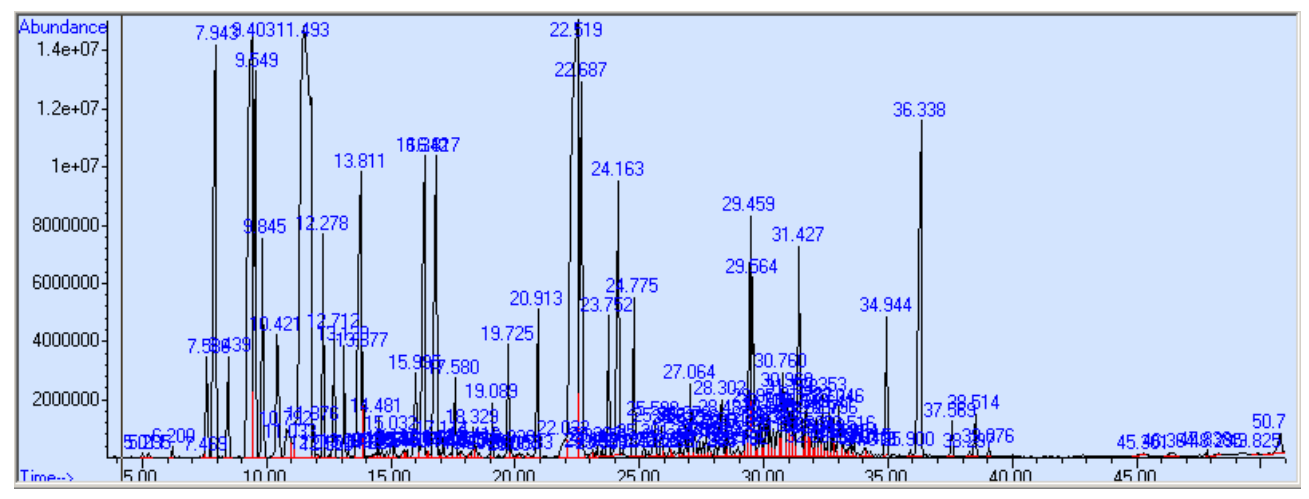

Fig. 1. Gas chromatographic-flame ionization detector (GC-FID) profile of the essential oil of leaves of Laurus nobilis.

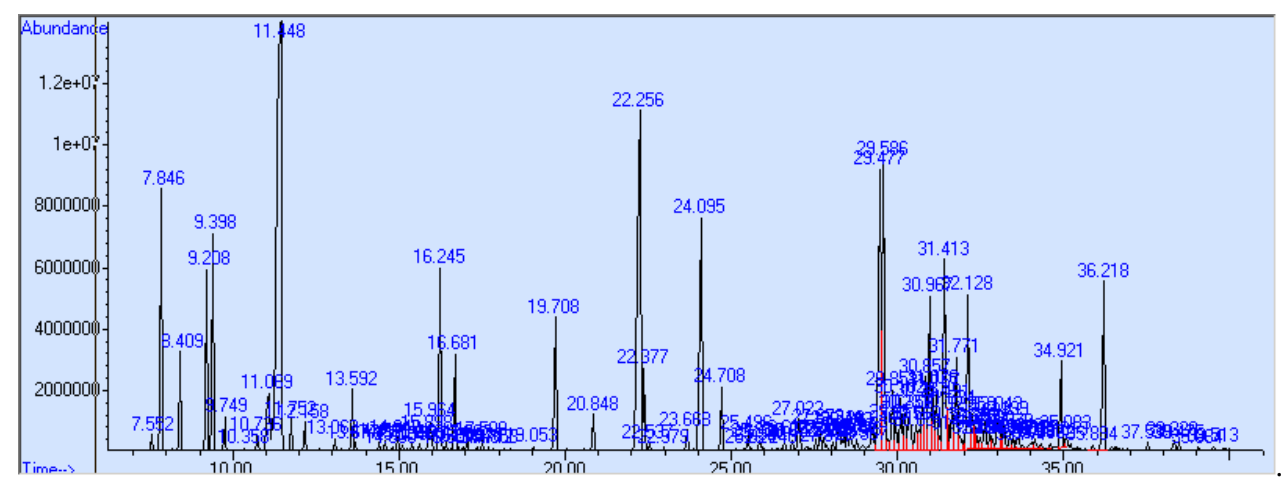

Fig. 2. Gas chromatographic-flame ionization detector (GC-FID) profile of the essential oil of seeds of Laurus nobilis.

In different studies, the essential oil constituents of L. nobilis leaves from Turkey, namely eucalyptol (59.94, 44.72, 35.63\%), $\alpha$-terpinyl acetate $(16.33,12.95,20.26 \%)$, sabinene $(8.70$, $12.82,6.10 \%)$, $\alpha$-pinene $(2,61,3.44,8.02 \%)$ were reported to be the major compounds, respectively (Sangun et al. 2007, Ozcan et al. 2010, Yilmaz and Deniz 2017). In this study, L. nobilis leave and seed EOs have similar chemical compositions with much lower concentration of the first major compound, eucalyptol (18.10-17.2 \%), followed by low or high concentrations of the other constituents (Table 1). 
Table 1. Chemical composition of the leaves and seeds of Laurus nobilis.

\begin{tabular}{|c|c|c|c|c|}
\hline No. & Compounds & RI & $\begin{array}{l}\text { Leaves } \\
(\%)\end{array}$ & $\begin{array}{l}\text { Seeds } \\
(\%)\end{array}$ \\
\hline 1 & 2-hexenal & 964 & 0,1 & - \\
\hline 2 & Isopropyl-2-methyl butyrate & 985 & 0,1 & - \\
\hline 3 & Tricyclene & 1013 & 0,1 & - \\
\hline 4 & $\alpha$-thujene & 1016 & 0,8 & 0,2 \\
\hline 5 & $\alpha$-pinene & 1022 & 4,5 & 3,3 \\
\hline 6 & Camphene & 1034 & 0,7 & 1,1 \\
\hline 7 & Sabinene & 1052 & 7,8 & 2,2 \\
\hline 8 & $\beta$-pinene & 1059 & 3,4 & 2,7 \\
\hline 9 & $\beta$-myrcene & 1066 & 1,6 & 0,4 \\
\hline 10 & $\alpha$-phellandrene & 1077 & 1,5 & 0,1 \\
\hline 11 & $\alpha$-terpinene & 1085 & 0,6 & 0,3 \\
\hline 12 & $o$-cymene & 1092 & 0,1 & - \\
\hline 13 & $m$-cymene & 1093 & - & 1,5 \\
\hline 14 & Eucalyptol (1,8-cineol) & 1102 & 18 & 17,2 \\
\hline 15 & $\beta$-ocimene & 1110 & 0,1 & 0,3 \\
\hline 16 & $\gamma$-terpinene & 1117 & 1,1 & 0,3 \\
\hline 17 & trans-sabinene-hydrate & 1129 & 0,7 & - \\
\hline 18 & $\alpha$-terpinolene & 1138 & 0,5 & 0,1 \\
\hline 19 & 2-nonanone & 1141 & 0,1 & - \\
\hline 20 & Linalool & 1148 & 4,2 & 0,7 \\
\hline 21 & 6-methyl- 3,5 heptadien-2-one & 1150 & - & 0,1 \\
\hline 22 & 1-terpineol & 1154 & 0,4 & - \\
\hline 23 & $p$-mentha-trans- 2,8 dien-diol & 1165 & 0,1 & - \\
\hline 24 & $p$-menth-2-en-1-ol & 1166 & - & 0,1 \\
\hline 25 & 4-acetyl-1-methyl cyclohexene & 1170 & - & 0,1 \\
\hline 26 & trans-pinocarveol & 1178 & - & 0,2 \\
\hline 27 & Pinocarvone & 1193 & - & 0,1 \\
\hline 28 & $\delta$-terpineol & 1199 & - & 0,3 \\
\hline 29 & Borneol & 1200 & - & 0,4 \\
\hline 30 & 4-terpineol & 1209 & 2,9 & 2,7 \\
\hline 31 & $\alpha$-terpineol & 1216 & 3,1 & 1,4 \\
\hline 32 & 1-cyclohexylpropadiene & 1222 & - & 0,1 \\
\hline 33 & cis-piperitol & 1225 & 0,1 & 0,1 \\
\hline 34 & $(+)$ trans-carveol & 1231 & 0,1 & 0,1 \\
\hline 35 & Nerol & 1234 & - & 0,1 \\
\hline 36 & trans-geraniol & 1236 & 0,5 & - \\
\hline 37 & Isocarveol & 1239 & - & 0,1 \\
\hline 38 & Homoveratrole & 1242 & - & 0,1 \\
\hline 39 & Carvol & 1250 & 0,1 & - \\
\hline 40 & Linalyl acetate & 1252 & 0,2 & - \\
\hline
\end{tabular}




\begin{tabular}{|c|c|c|c|c|}
\hline 41 & Geraniol & 1254 & 0,1 & - \\
\hline 42 & Piperitone & 1258 & 0,1 & - \\
\hline 43 & Bornyl acetate & 1283 & 0,7 & 2,1 \\
\hline 44 & 2-undecanone & 1289 & 0,1 & - \\
\hline 45 & Perilla alcohol & 1300 & 0,1 & - \\
\hline 46 & $\alpha$-terpinyl acetate & 1338 & 13,1 & 9 \\
\hline 47 & Eugenol & 1341 & 4,2 & 1,1 \\
\hline 48 & Neryl acetate & 1345 & - & 0,1 \\
\hline 49 & Ylangene & 1354 & - & 0,1 \\
\hline 50 & Geranyl acetate & 1361 & 0,1 & - \\
\hline 51 & $\beta$-bourbonene & 1367 & 0,1 & - \\
\hline 52 & $\beta$-elemene & 1371 & 0,9 & 0,3 \\
\hline 53 & Methyl eugenol & 1380 & 2,6 & 4,2 \\
\hline 54 & $\alpha$-gurjunene & 1384 & 0,1 & - \\
\hline 55 & $\beta$-caryophyllene & 1394 & 0,9 & 0,9 \\
\hline 56 & $\alpha$-guaiene & 1403 & 0,1 & - \\
\hline 57 & Epizonaren & 1407 & 0,1 & - \\
\hline 58 & trans-cinnamyl acetate & 1410 & - & 0,2 \\
\hline 59 & trans-isoeugenol & 1412 & 0,3 & - \\
\hline 60 & Epizonarene & 1413 & - & 0,1 \\
\hline 61 & $\alpha$-humulene & 1418 & 0,2 & 0,1 \\
\hline 62 & 10s,11s-himachala-3(12),4-diene & 1419 & - & 0,1 \\
\hline 63 & Aromadendrene & 1420 & 0,1 & - \\
\hline 64 & $\alpha$-selinene & 1429 & 0,1 & - \\
\hline 65 & (+) epibicyclosesquiphellandrene & 1434 & - & 0,2 \\
\hline 66 & Germacrene-D & 1435 & 0,2 & - \\
\hline 67 & $\beta$-selinene & 1440 & 0,2 & 0,2 \\
\hline 68 & Methyl isoeugenol & 1443 & - & 0,6 \\
\hline 69 & Bicyclogermacrene & 1444 & 0,6 & - \\
\hline 70 & Eremophila-1(10),11-diene & 1452 & 0,1 & - \\
\hline 71 & $\alpha$-amorphene & 1455 & 0,1 & 0,2 \\
\hline 72 & $\delta$-cadinene & 1458 & 0,2 & 0,3 \\
\hline 73 & L-calamenene & 1460 & - & 0,2 \\
\hline 74 & cis- $\alpha$ bisabolene & 1471 & 0,6 & - \\
\hline 75 & $\alpha$-copaen-11-ol & 1473 & - & 0,3 \\
\hline 76 & $\beta$-asarone & 1475 & 0,2 & 0,3 \\
\hline 77 & Hedycaryol & 1477 & - & 0,2 \\
\hline 78 & Elemol & 1478 & 0,2 & - \\
\hline 79 & Corodane & 1486 & - & 0,2 \\
\hline 80 & $\beta$-humulene & 1491 & 0,1 & - \\
\hline 81 & Spathulenol & 1497 & 1,8 & 5 \\
\hline 82 & Caryophyllene oxide & 1500 & 1,4 & 6,1 \\
\hline 83 & Ledol & 1505 & 0,7 & 1,8 \\
\hline
\end{tabular}




\begin{tabular}{lllll}
\hline 84 & 4-Bromo-1-naphthylamine & 1517 & 0,3 & - \\
85 & $\gamma$-selinene & 1521 & 0,3 & 0,4 \\
86 & Epiglobulol & 1523 & - & 0,4 \\
87 & Alloaromadendrene & 1525 & 1,1 & 0,9 \\
88 & Aromadendrene & 1528 & - & 1,2 \\
89 & Caryophylladienol I & 1530 & 0,5 & 2,1 \\
90 & trans-isoelemicin & 1532 & - & 1,1 \\
91 & Thujopsene & 1534 & - & 0,8 \\
92 & Valencene-1 & 1535 & 0,6 & - \\
93 & t-muurolol & 1540 & 1,9 & 3,7 \\
94 & $\gamma$-gurjunene & 1545 & 0,3 & - \\
95 & Aromadendrene epoxide & 1547 & 0,5 & - \\
96 & 2-hexyl-1-decen-3-yne & 1558 & - & 0,5 \\
97 & 1-amino-4-bromonaphtalene & 1576 & 0,6 & 0,8 \\
98 & $\beta$-oplopenone & 1592 & - & 0,1 \\
99 & (+)- $\beta$-costol & 1597 & - & 0,2 \\
100 & (+)-eremophilene & 1603 & - & 0,1 \\
101 & B-panasinsene & 1604 & 0,1 & - \\
102 & 3-ethyl-6(methoxycarbonyl)2-naphthol & 1617 & 0,9 & 3,9 \\
103 & 2-(4-methoxyphenyl)-N,N,2-trimethyl-1- & 1648 & 4,4 & - \\
& pyrroline & & & - \\
104 & n-hexadecanoic acid & 1691 & 0,1 & 0,2 \\
105 & Heptadecane & 1901 & 0,1 & - \\
106 & 17-pentatriacantone & 1911 & 0,1 & - \\
107 & Cyclotetracosane & 1944 & 0,1 & \\
& Total & & 95,8 & \\
\hline
\end{tabular}

RI: Retention indices.

On the other hand, isoeugenol $(53.5,57.0 \%)$ and linalool (42.61\%) were the main compounds of EOs of $L$. nobilis leaves from Brazil and India. Furthermore, 1,8-cineole and $\alpha$-pinene have been described as minor compounds in L. nobilis essential oils, which is in contrast with the results of the present study (Peixoto et al. 2017, Pinheiro et al. 2017, Choudhary et al. 2013, Chahal et al. 2017). In this study, the lowest concentration of 1,8-cineole was reported from Turkey (Karık et al. 2015). Although the major compounds in EO scan vary, several studies have shown that the major compounds of $L$. nobilis essential oil are mono- and sesquiterpene hydrocarbons (Basak and Candan 2013, Cherrat et al. 2014, Goudjil et al. 2015, Peixoto et al. 2017), which are in agreement with the present results. Saab et al. (2012) reported that, $\beta$ ocimene, 1,8-cineole, $\alpha$-pinene and $\beta$-pinene were the main compounds of seed essential oils of $L$. nobilis from Italy, in which 27 compounds were identified in the essential oil of the seeds (Saab et al. 2012). The present samples constituted 1,8-cineole and $\alpha$-pinene as the major compounds, while $\beta$-ocimene and $\beta$-pinene were determined as minor compounds.

The yield and composition of essential oil varies with genetic and environmental factors, as well as developmental stage and extraction methods like steam distillation, hydro distillation and soxhlet extraction (Woolf 1999). Karık et al. (2015) reported 1,8-cineole as the first major compound of the EO of L. nobilis from five different locations of Sinop province. However, in this report, sabinene, $\alpha$-pinene and $\alpha$-terpinyl acetate were not determined in some of the samples of 
L. nobilis leaves. Therefore, it may be suggested that seasonal variations affect the chemical profile of the EO.

The results obtained from this study represent that the EOs obtained in different phenological stages displays similar compositions. The main compounds of $L$. nobilis EO were determined as 1,8-cineole, trans-sabinene hydrate, $\alpha$-terpinyl acetate, methyl eugenol, sabinene, eugenol, $\alpha$ pinene and $\alpha$-terpineol (Verdian-rizi 2009). A number of studies on the chemical composition of the EO obtained from different parts of $L$. nobilis harvested from various regions of Turkey were published. However, this study is the first one presenting the chemical composition of the EO of L. nobilis seeds from Black Sea region of Turkey.

In conclusion, it may be mentioned that EO composition of the members of Laurus displays similarity. The essential oil compositions of different parts of Laurus samples have also shown that they can be used as raw material for medicinal and pharmaceutical purposes and natural products.

\section{Acknowledgments}

This work was supported by Sinop University Scientific Research Coordination Unit. Project Number: 1901. 14-05, 2015.

\section{References}

Afifi FU, Khalil E, Tamimi SO and Disi A 1997. Evaluation of the gastro protective effect of L. nobilis seeds on ethanol induced gastric ulcer in rats. J. Ethnopharmacol. 58: 9-14

Aqili MS 1992. Collection of drugs (Materia media). Enqelab-e-Eslami Publishing and Educational Organization. Tehran. 624-630.

Basak SS and Candan F 2013. Effect of Laurus nobilis L: Essential oil and its maincomponents on aglucosidase and reactive oxygen species scavenging activityIran. J. Pharm. Sci. 12: 367-379.

Baytop T1984. Therapy with Medicinal Plants in Turkey. Publications of Istanbul University, Istanbul; 194.

Bouzouita N, Nafti A, Chaabouni MM, Lognay GC, Marlier M, Zghoulli S and PH. Thonart 2001. Chemical composition of Laurus nobilis oil from Tunisia, J. Essent. Oil Res. 13: 116-117.

Bozan B and Karakaplan U 2007. Antioxidants from laurel (Laurus nobilis L.) berries: influences of extraction procedure on yield and antioxidant activity of extracts. Acta Alim. 36: 321-328.

Caputo L, Nazzaro F, Souza LF, Aliberti L, DeMartino L, Fratianni F, Coppola R and De Feo V 2017. Laurus nobilis: Composition of essential oil and its biological activities. Molecules 22: 930.

Chahal KK, Kaur M, Bhardwaj U, Singla N and Kaur A 2017. A review on chemistry and biological activities of Laurus nobilis L. essential oil. J. Pharmacogn Phytochem. 6: 1153-1161.

Cherrat L, Espina L, Bakkali M, García-Gonzalo D, Pagán R and Laglaoui A 2014. Chemical composition and antioxidant properties of Laurus nobilis L: and Myrtus communis L. essential oils from Morocco and evaluation of their antimicrobialactivity acting alone or in combined processes for food preservation. J. Sci. Food Agric. 94: 1197-1204.

Choudhary D, Kala SP, Todaria NP, Dascupta S, Kinhal G and Kollmair M 2013. Essential oil from bay leaves in India and Nepal: An analysis for quality oriented value chain development. IJMAP 3: 11-17.

Conforti F, Statti G, Uzunov D and Menichini F 2006. Comparative chemical composition and antioxidant activities of wild and cultivated Laurus nobilis L. leaves and Foeniculum vulgare subsp. piperitum (Ucria) Coutinho seeds. Biol. Pharm. Bull. 29: 2056-64.

Demir V, Gunhan T, Yagcioglu AK and Degirmencioglu A 2004. Mathematical modelling and the determination of some quality parameters of air-dried bay leaves. Biosyst. Eng. 88: 325-335.

Duke JA 1997. The green pharmacy. In: New discoveries in herbal remedies for common diseases and conditions from the world's foremost authority on healing herbs. Rodale Press, New York, 240-241. 
Erturk O 2006. Antibacterial and antifungal activity of ethanolic extracts from eleven spice plants. Biologia. 61: $275-278$.

Garg SN, Siddiqui MS and Agarwal SK 1992. New fatty acid esters and hydroxyl ketones from fruits of Laurus nobilis. J. Nat. Prod. 55: 1315-1319.

Goudjil MB, Segni L, Bencheikh SE, Zighmi S and Hamada D 2015. Study of the chemical composition: antibacterial and antioxidant activities of the essentialoil extracted from the leaves of Algerian Laurus nobilis Lauraceae. J. Chem. Pharm. Res. 7: 379-385.

Gulcin I 2006. Toxicology. 213.

Isbilir SS, Ozcan HM and Yagar H 2008. Some biochemical properties of lipase from bay Laurel (Laurus nobilis L.) Seeds. J. Am. Oil. Chem. Soc. 85: 227-233.

Karık Ü, Çiçek F, Oğur E, Tutar M and Ayas F 2015. Türkiye Defne (Laurus nobilis L.) Populasyonlarının Uçucu Yağ Bileşenleri. ANADOLU, J. of AARI. 25: 1-16.

Kilic A, Hafizoglu H, Kollmannsberger H and Nitz S 2004. Volatile constituents and key odorants in leaves, buds, flowers, and fruits of Laurus nobilis L. J. Agric. Food Chem. 52: 1601-1606.

Kovacevic NN, Simic MD and Risti MS 2007. Essential oil of Laurus nobilis from Montenegro. Chem. Nat. Compd. 43: 408-411.

Ozcan B, Esen M, Sangun MK, Coleri A and Caliskan M 2010. Effective antibacterial and antioxidant properties of methanolic extract of Laurus nobilis seed oil. J. Environ. Biol. 31: 637-641.

Patrakar R, Mansuriya M and Patil P 2012. Phytochemical and pharmacological review on Laurus Nobilis. Int. Journal of Chem. and Pharm. Sciences 1: 595-602.

Peixoto LR, Rosalen PL, Ferreira GL, Freires IA, de Carvalho FG, Castellano LR and de Castro RD 2017. Antifungal activity, mode of action and anti-biofilm effects of Laurus nobilis Linnaeus essential oil against Candida spp. Arch. Oral Biol.73: 179-185.

Pinheiro LS, Filho AAO, Guerra FQS, Menezes CP, Santos SG, Sousa JP, Dantas TB and Lima EO2017. Antifungal activity of the essential oil isolated from Laurus nobilis L. against Cryptococcus neoformans strains. J. Appl. Pharm. Sci. 7: 115-118.

Pirbalouti AG, Sedaghat L, Hamedi B and Tirgir F 2013. Chemical composition and antioxidant activity of essential oils of three endemic medicinal plants of Iran. Bangladesh J. Bot. 42: 327-332.

Ramosa C, Teixeiraa B, Batistaa I, Matosb O, Serranoc C, Nengd NR, Nogueirad JMF, Nunesa ML and Marques A 2012. Antioxidant and antibacterial activity of essential oil and extracts of bay laurel Laurus nobilis Linnaeus (Lauraceae) from Portugal. Nat. Prod. Res. 26: 518-529.

Saab AM, Tundis R, Loizzo MR, Lampronti I, Borgatti M, Gambari R, Menichini F, Esseily F and Menichini F 2012. Antioxidant and ant proliferative activity of Laurus nobilis L. (Lauraceae) leaves and seeds essential oils against K562 human chronic myelogenous leukemia cells. Nat. Prod. Res. 26: 1741-1745.

Sangun MK, Aydın E, Timur M, Karadeniz H, Caliskan M and Ozkan A 2007. Comparison of chemical composition of the essential oil of Laurus nobilis L. leaves and fruits from different regions of Hatay, Turkey. J. Environ. Biol. 28: 731-733.

Sayyah M, Saroukhani G, Peirovi A and Kamalinejad M 2003. Analgesic and anti-inflammatory activity of the leaf essential oil of Laurus nobilis Linn. Phytother. Res. 17: 733-736.

Sellami IH, Wannes WA, Bettaieb I, Berrima S, Chahed T, Marzouk B and Limam F 2011. Qualitative and quantitative changes in the essential oil of Laurus nobilis L. leaves as affected by different drying methods. Food Chem. 126: 691-697.

Simic M, Kundakovic T and Kovacevic N 2003. Preliminary assay on the antioxidative activity of Laurus nobilis extracts. Fitoterapia 74: 613-616.

Verdian-rizi M 2009. Variation in the essential oil composition of Laurus nobilis L. of different growth stages cultivated in Iran. J. Basic Appl. Sci. 5: 33-36.

Woolf A 1999. Essential oil poisoning. J. Toxicol. Clin. Toxicol. 37: 721-727.

Yalçın H, Akın M, Sanda MA and Çakır A 2007. Gas chromatography/mass spectrometry analysis of Laurus nobilis essential oil composition of Northern Cyprus. J. Med. Food.10: 715-719. 
Yazıcı H 2002. Batı Karadeniz Bölgesinde Yetișen Defne (Laurus nobilis L.) Yaprak ve Meyvelerinden Faydalanma İmkânlarının Araştırılması. Zonguldak Karaelmas Üniversitesi. Fen Bilimleri Enstitüsü, Yayınlanmamış Doktora Tezi, 309.

Yllmaz B and Deniz İ 2017. The Effects of cultivation area and altitude variation on the composition of essential oil of Laurus nobilis L. grown in eastern, Western and Central Karadeniz Region. Int. J. Sec. Metabolite 4: 187-194.

(Manuscript received on 5 may, 2018; revised on 20 May, 2018) 